\title{
Classification and Engineering Properties of Unknown Variety of Oil Palm Kernels from Nigeria
}

\author{
S.L. Ezeoha ${ }^{1}$ and C.O. Akubuo ${ }^{2}$ \\ ${ }^{1,2}$ Department of Agricultural and Bioresources Engineering \\ University of Nigeria, Nsukka, Enugu State 410001, Nigeria.
}

\begin{abstract}
The average size of oil palm kernels of unknown variety was used to classify their varietal composition. Engineering properties of oil palm kernels are important for rational design of general- purpose handling systems for oil palm kernels. In this work, average values of size, solid density, bulk density, compressive yield load, hardness, angle of repose, porosity, sphericity, and coefficient of friction were determined for samples of unknown variety of palm kernels sourced from three local markets in Nsukka, Enugu state, Nigeria. At an average moisture content of $6.1 \%$ (w.b.), the major diameter ranged between $15.68 \pm 2.24$ $\mathrm{mm}$ and $22.41 \pm 2.19 \mathrm{~mm}$ with an average of $19.09 \pm 2.01 \mathrm{~mm}$. The solid density ranged between $1.00 \pm 0.09$ $\mathrm{g} / \mathrm{cm}^{3}$ and $1.32 \pm 0.02 \mathrm{~g} / \mathrm{cm}^{3}$ with an average value of $1.17 \pm 0.13 \mathrm{~g} / \mathrm{cm}^{3}$. Other average values were $608.05 \pm$ $14.08 \mathrm{~kg} / \mathrm{m}^{3}$ for bulk density; $1022.44 \pm 90.56 \mathrm{~N}$ for compressive yield strength; $10.41 \pm 0.09 \mathrm{kN} / \mathrm{m}^{2}$ for hardness; $37.75 \pm 1.33^{\circ}$ for angle of repose; $47.4 \pm 7.7 \%$ for porosity; and $0.74 \pm 0.04$ for sphericity. The average coefficients of friction were $0.52 \pm 0.05,0.51 \pm 0.03$, and $0.46 \pm 0.06$ on plywood, galvanized steel, and glass surfaces respectively. The size analyses results showed that the oil palm kernels used in this study were mixtures of dura, tenera, and pisifera varieties. Moisture content of the kernel was found to influence most of the properties
\end{abstract}

Keywords: - Palm kernel, engineering properties, unknown variety, oil palm, Nigeria

\section{INTRODUCTION}

Some engineering properties of agricultural seeds and kernels considered important for the rational design of their handling, processing, and storage systems include: bulk density, solid density, compressive strength, hardness, toughness, specific heat capacity, and coefficient of sliding friction, angle of repose, size, and shape $[1,2,3,4,5$,$] . The size and shape of agricultural seeds are important in the design of hoppers, press$ auger, and press barrel for efficient oil extraction using the screw press. They are also important in the design of grading or cleaning equipment $[6,7,8$, and 9]. The solid and bulk densities are important in the design of hoppers also, and for computing the throughput and the performance efficiencies of oilseed's screw presses [10, 11, and 12]. The knowledge of rupture resistance, toughness, deformation, and hardness of oilseeds is important in determining power requirements during size reduction and pressing operations, and for proper selection of construction materials for handling equipment $[13,14,15$, and 9]. The specific heat capacity of palm kernels is useful in the determination of the amount of heat required for enhanced oil expression from oilseeds, and hence aids in the selection of the best pressing method [9]. The coefficient of sliding friction is important in the determination of the steepness of hoppers, storage containers and power requirement calculations $[10,12,16$, and 9]. Angle of repose is important in the design of their storage structures [9].

Oil palm kernels occur in three known varieties, namely dura, pisifera, and tenera. The two known sources of oil palm kernels are the modern plantations and the wild groves. The wild groves, as the name implies, often grow untended. They are found in clusters and are mainly the result of natural seed dispersal. Oil palm kernels sourced from established plantations are easily classified based on the variety of the palm trees cultivated. But, kernels sourced from open markets where most small to medium-scale processors procure their materials are not classified because these kernels come mostly from wild grove oil palm trees that are usually of unknown variety. The engineering properties of dura, pisifera, and tenera varieties have been determined by other researchers. Koyaet al. [16] determined some properties of the dura, tenera, and pisifera varieties of oil palm kernels. The properties included size, sphericity, density, and coefficient of friction. Gbadamosi [9] also determined some engineering properties of oil palm kernels, for the three varieties, and the properties included size, shape, coefficient of friction, hardness, specific heat capacity, and compressive strength. Ozumba and Obiakor[17] determined the average compressive rupture force, deformation and toughness of the dura variety. There is, therefore, need to determine the engineering properties of oil palm kernels of unknown variety. The average size could be used to classify the kernels into known varieties. And the average values of other engineering properties are considered more relevant for rational design of general-purpose handling systems 
than using the specific values published for tenera, pisifera, or dura varieties. Thus, the objectives of this study were:

1. To determine the average values of the size, sphericity, solid density, bulk density, compressive yield strength, hardness, angle of repose, and coefficient of sliding friction of oil palm kernels of unknown variety procured from three local markets in Nsukka, Enugu state, Nigeria;

2. To classify the kernels into known varieties based on their sizes;

3. And to determine whether kernel moisture content has effect on some of the kernel properties.

\section{MATERIALS AND METHODS}

Five batches of unknown variety of palm kernels were purchased on five different days from three different open markets in Nsukka Local Government Area in Enugu State of Nigeria. The kernels were cleaned manually to remove dirt and other foreign materials. The batches were graded using three sieves, A, B, C, with $12.70,9.52$, and $6.7 \mathrm{~mm}$-diameter apertures respectively, with a view to classifying them intoknown palm kernel varieties based on size. The aperture sizes of the three sieves were chosen, because based on average kernel sizes given by Gbadamosi (2006), palm kernels retained on sieve sizes of $12.70 \mathrm{~mm}$ and $9.52 \mathrm{~mm}$ are likely to be either dura or tenera variety or both; while those retained on sieve size of $6.7 \mathrm{~mm}$ after passing through the other two sieve sizes are likely to be pisifera. The moisture contents of the samples were determined by ovendrying ground samples $(100 \mathrm{~g})$ at $103^{\circ} \mathrm{C}$ for $6 \mathrm{hrs}$. Grade $1^{\mathrm{A}}$ stands for a sample of batch 1 retained on sieve 'A'. Grade $2^{\mathrm{A}}$ stands for a sample of batch 2 retained on sieve ' $A$ '. Grade $2^{\mathrm{B}}$ stands for a sample of batch 2 retained on sieve ' $\mathrm{B}$ '. Grade $3^{\mathrm{A}}$ is a sample of batch 3 retained on the sieve ' $\mathrm{A}$ '. Grade $4^{\mathrm{A}}$ is sample of batch 4 retained on sieve 'A'. Grade $4^{\mathrm{B}}$ is a sample of batch 4 retained on sieve ' $\mathrm{B}$ '. Grade $5^{\mathrm{B}}$ is a sample of batch 5 retained on sieve ' $\mathrm{B}$ '. And grade $5^{\mathrm{C}}$ is a sample of batch 5 retained on sieve ' $\mathrm{C}$ '.

For the determination of size and shape of palm kernels, twenty randomly chosen kernels representative of each grade were measured. A Vernier caliper with $0.01 \mathrm{~mm}$ accuracy was used to measure the three axial dimensions of the kernels namely, the major, intermediate, and minor diameters of the kernels. The shape of the kernels was described in terms of their sphericity. The solid density of palm kernel was obtained by dividing the mass of a sample kernel by its volume. The mass of 20-seeds sample enclosed in a tight-fitting plastic bag to prevent water seepage was measured with an electronic scale, and the volume obtained by water displacement. The test was replicated five times. The bulk density of palm kernels was determined by finding the ratio of the mass of a sample to its total volume freely filling a container without compaction. The container used was a $100 \mathrm{~mm}$ long, $50 \mathrm{~mm}$-diameter cylindrical container. The measurements were replicated 5 times. The hardness of the palm kernels was determined using a hardness testing machine (Model No. 174886 by Ogawa Seiki Co. Ltd. Japan). The machine had a compression spindle and a loading surface. With a kernel on the loading surface, the spindle was used to produce indentation on it. The hardness value was read on a graduated scale. The test was replicated five times.

The coefficient of sliding friction of palm kernels was determined for three structural surfaces namely, plywood, galvanized steel, and glass. Twenty seeds of palm kernels were placed on each structural surface measuring $50 \mathrm{~mm}$ by $200 \mathrm{~mm}$ which was attached to an adjustable tilting surface. One end of the tilting platform was gradually raised with a wedge until some kernels just started to slide down the structural surface on the inclined platform. The tangent of the angle of tilt at the initiation of free sliding was taken as the coefficient of sliding friction. Five observations were made per structural surface. Angle of repose of palm kernels was determined by piling the kernels on a circular platform apparatus in the Food and Bioprocess Engineering Laboratory of Agricultural and Bioresources Engineering Department, University of Nigeria, Nsukka. The conical heap formed was measured with respect to its vertical height and diameter. The angle of repose was computed from the ratio of the vertical height of the heap to the true length (slant height) of the heap (Gbadamosi, 2006). The experiment was replicated 5 times. Compression tests on palm kernels were performed with a Monsanto Tensometerin the Civil Engineering laboratory of University of Nigeria, Nsukka, following standard procedure [18] for each sample seed and replicated 3 times. The loads at yield points were recorded.

\section{RESULTS AND DISCUSSION}

The moisture content (\% wet basis) of the test samples at the time of the experiments were 7.3 for batch 1, 7.0 for batch 2, 4.5 for batch 3, 8.0 for batch 4, 3.8 for batch 5. The average moisture content of the mixture was $6.1 \%$ w.b. Table 1 presents a summary of all the engineering properties that were determined. The major diameter ranged between $15.68 \pm 2.24 \mathrm{~mm}$ and $22.41 \pm 2.19 \mathrm{~mm}$ with an average of $19.09 \pm 2.01 \mathrm{~mm}$. The intermediate diameter ranged between $9.77 \pm 0.70 \mathrm{~mm}$ and $15.76 \pm 1.10 \mathrm{~mm}$ with an average of $13.84 \pm$ $1.17 \mathrm{~mm}$. And the minor diameter ranged between $7.72 \pm 1.25 \mathrm{~mm}$ and $12.12 \pm 1.55 \mathrm{~mm}$ with an average of $10.82 \pm 1.43 \mathrm{~mm}$. Grades $1^{\mathrm{A}}, 2^{\mathrm{A}}, 3^{\mathrm{A}}$ and $4^{\mathrm{A}}$ were retained on A-sieve, because their average major and intermediate diameters (including their minimum values) were all greater than the sieve's aperture. Grades $2^{\mathrm{B}}$, $4^{\mathrm{B}}, 5^{\mathrm{B}}$ and $5^{\mathrm{C}}$ all passed through $\mathrm{A}$-sieve because their average intermediate and minor diameters (including 
their minimum values) were smaller than the sieve's apertures. They were, however, retained on sieve 'B', because their average major and intermediate diameters (including their minimum values) were all greater than the sieve's aperture. Grade $5^{\mathrm{C}}$ passed through B-sieve with $9.52 \mathrm{~mm}$ apertures but was retained on C-sieve with $6.7 \mathrm{~mm}$ aperture following the same principle.

Table 1: Average Values of Some Engineering Properties of the Unknown Variety of Oil Palm Kernels

\begin{tabular}{|c|c|c|c|c|c|c|c|c|c|c|}
\hline $\begin{array}{c}\mathrm{P} \\
1^{\mathrm{A}} 2^{\mathrm{A}} 2^{\mathrm{B}}\end{array}$ & & $3^{\mathrm{A}}$ & & $4^{\mathrm{A}}$ & $4^{\mathrm{B}} \quad \begin{array}{r}\mathrm{G} \\
5^{\mathrm{B}} 5^{\mathrm{C}}\end{array}$ & $\begin{array}{l}\text { irade } \\
\text { value }\end{array}$ & & & & Mean \\
\hline $\begin{array}{l}\text { MJD } \\
(\mathrm{mm})\end{array}$ & 20 & $\begin{array}{r}22.41 \\
(2.19)\end{array}$ & $\begin{array}{l}19 . \\
(1.5\end{array}$ & $\begin{array}{lr}45 & 17.17 \\
3) & (1.81)\end{array}$ & $\begin{array}{l}19.01 \\
(1.72)\end{array}$ & $\begin{array}{l}22.33 \\
(1.55)\end{array}$ & $\begin{array}{l}19.31 \\
(2.62)\end{array}$ & $\begin{array}{l}17.36 \\
(2.47)\end{array}$ & $\begin{array}{l}15.6819 \\
(2.24)\end{array}$ & $\begin{array}{l}19.01 \\
(2.01)\end{array}$ \\
\hline $\begin{array}{l}\text { ID } \\
(\mathrm{mm})\end{array}$ & 20 & $\begin{array}{l}15.76 \\
(1.10)\end{array}$ & $\begin{array}{l}15.0 \\
(1.06\end{array}$ & $\begin{array}{ll}1 & 12.23 \\
5) & (1.10)\end{array}$ & $\begin{array}{l}15.03 \\
(1.41)\end{array}$ & $\begin{array}{l}17.42 \\
(1.55)\end{array}$ & $\begin{array}{l}13.05 \\
(1.20)\end{array}$ & $\begin{array}{l}12.48 \\
(1.22)\end{array}$ & $\begin{array}{c}9.77 \quad 1 \\
(0.70)\end{array}$ & ${ }^{13.84}(1.17)$ \\
\hline $\begin{array}{l}\text { MND } \\
(\mathrm{mm})\end{array}$ & 20 & $\begin{array}{l}12.12 \\
(1.55)\end{array}$ & $\begin{array}{l}12.0 \\
(1.48\end{array}$ & $\begin{array}{cc}4 & 9.06 \\
3) & (1.35)\end{array}$ & $\begin{array}{l}11.87 \\
(1.68)\end{array}$ & $\begin{array}{l}12.65 \\
(1.46)\end{array}$ & $\begin{array}{r}10.39 \\
(1.31)\end{array}$ & $\begin{array}{l}10.17 \\
(1.33)\end{array}$ & $\begin{array}{ll}7.72 & 1 \\
(1.25) & \end{array}$ & $\begin{array}{l}10.82 \\
(1.43)\end{array}$ \\
\hline $\begin{array}{l}\text { SPH } \\
(0.04)\end{array}$ & 20 & 0.72 & 0.78 & 0.74 & 0.78 & 0.76 & 0.71 & 0.75 & 0.67 & 0.74 \\
\hline $\begin{array}{l}\mathrm{HDN} \\
\left(\mathrm{kN} / \mathrm{m}^{2}\right)\end{array}$ & & 10.2110 & 0.48 & 10.23 & 0.4510 & .43 & $0.48 \quad 10$. & $50 \quad 10.48$ & $\begin{array}{rr}8 & 10.41 \\
& (0\end{array}$ & $\begin{array}{l}1 \\
(0.09)\end{array}$ \\
\hline $\begin{array}{l}\mathrm{BD} \\
\left(\mathrm{kg} / \mathrm{m}^{3}\right)^{5}\end{array}$ & & $\begin{array}{l}575.16 \\
(14.22)\end{array}$ & $\begin{array}{r}525 \\
6.02)\end{array}$ & $\begin{array}{c}14637.28 \\
(14.40)\end{array}$ & $\begin{array}{l}625.05 \\
(23.42)\end{array}$ & $\begin{array}{l}591.51 \\
(24.77)\end{array}$ & $\begin{array}{l}609.18 \\
(6.62)\end{array}$ & $\begin{array}{l}647.76 \\
(12.49)\end{array}$ & $\begin{array}{ll}553.29 & 60 \\
(10.73\end{array}$ & $\begin{array}{l}608.05 \\
\quad(14.08)\end{array}$ \\
\hline$\underset{\left(\mathrm{g} / \mathrm{cm}^{3}\right)}{\mathrm{SD}} 5$ & $\begin{array}{ll}5 & 1 \\
& (0\end{array}$ & $\begin{array}{l}1.32 \\
(0.02)\end{array}$ & $\begin{array}{r}1.20 \\
(0.12\end{array}$ & $\begin{array}{l}1.03 \\
(0.17)\end{array}$ & $\begin{array}{l}1.27 \\
(0.10)\end{array}$ & $\begin{array}{l}1.30 \\
(0.17)\end{array}$ & $\begin{array}{l}1.00 \\
(0.09)\end{array}$ & $\begin{array}{l}1.03 \\
0.21)\end{array}$ & $\begin{array}{l}1.02 \\
(0.08)\end{array}$ & $\begin{array}{l}1.17 \\
(0.13)\end{array}$ \\
\hline $\begin{array}{l}\text { PSTY } 5 \\
(\%)\end{array}$ & 55 & 56.40 & 56.30 & 38.20 & 50.80 & 54.50 & 49.30 & 37.10 & 36.70 & $\begin{array}{l}47.40 \\
(7.70)\end{array}$ \\
\hline $\begin{array}{ll}\text { SAR } & 5 \\
\left({ }^{\circ}\right) & \end{array}$ & 54 & 44 & - & - & - & $\begin{array}{l}39 \\
(1.7)\end{array}$ & - & $\begin{array}{l}35 \\
(1.1)\end{array}$ & $\begin{array}{l}33 \\
(1.4)\end{array}$ & $\begin{array}{l}37.75 \\
(1.33)\end{array}$ \\
\hline $\begin{array}{l}\text { CSF on } \\
\text { PWD } 5 \\
(0.04\end{array}$ & $\begin{array}{ll}5 & 0 . \\
4) & \end{array}$ & .52 & & $.03)^{0.51}$ & - & - & ${ }^{-}(0.06$ & 0.52 & $\begin{array}{rr}0.51 & 0 \\
& (0.05)\end{array}$ & 0.52 \\
\hline $\begin{array}{l}\text { CSF on } \\
\text { GS } 5 \\
\quad(0.03\end{array}$ & & 0.51 & $\bar{c}$ & $.04)^{0.50}$ & - & - & $(0.03)$ & $\begin{array}{l}0.51 \\
(0.03)\end{array}$ & $\begin{array}{r}0.50 \\
(0.03)\end{array}$ & 0.51 \\
\hline $\begin{array}{l}\text { CSF on } \\
\text { Glass } 5 \\
\quad(0.05\end{array}$ & 50. & .46 & & $0.06)^{0.46}$ & - & - & ${ }^{-}(0.0$ & 5) $\quad 0.47$ & 6) $\begin{array}{l}0.45 \\
\quad(0.06)\end{array}$ & 5) 0.46 \\
\hline
\end{tabular}

P (Property), R (Replications), MJD (major diameter), ID (intermediate diameter), MND (minor diameter), SPH (sphericity), HDN (hardness), BD( bulk density), SD(solid density), PSTY( porosity), SAR (static angle of repose), CSF (coefficient of sliding friction),PWD (plywood), GS (galvanized steel). Values in brackets are standard deviations).

This observed principle or trend is considered useful in the design of sieves for oil palm kernel grading and cleaning purposes based on the size. The trends of variation of some kernel properties with respect to kernel moisture contents for the different batches are depicted in Figs.1 - 7. Fig. 1 shows the variation of kernel size (major diameter) with moisture content (m.c.) of the five kernel batches. 


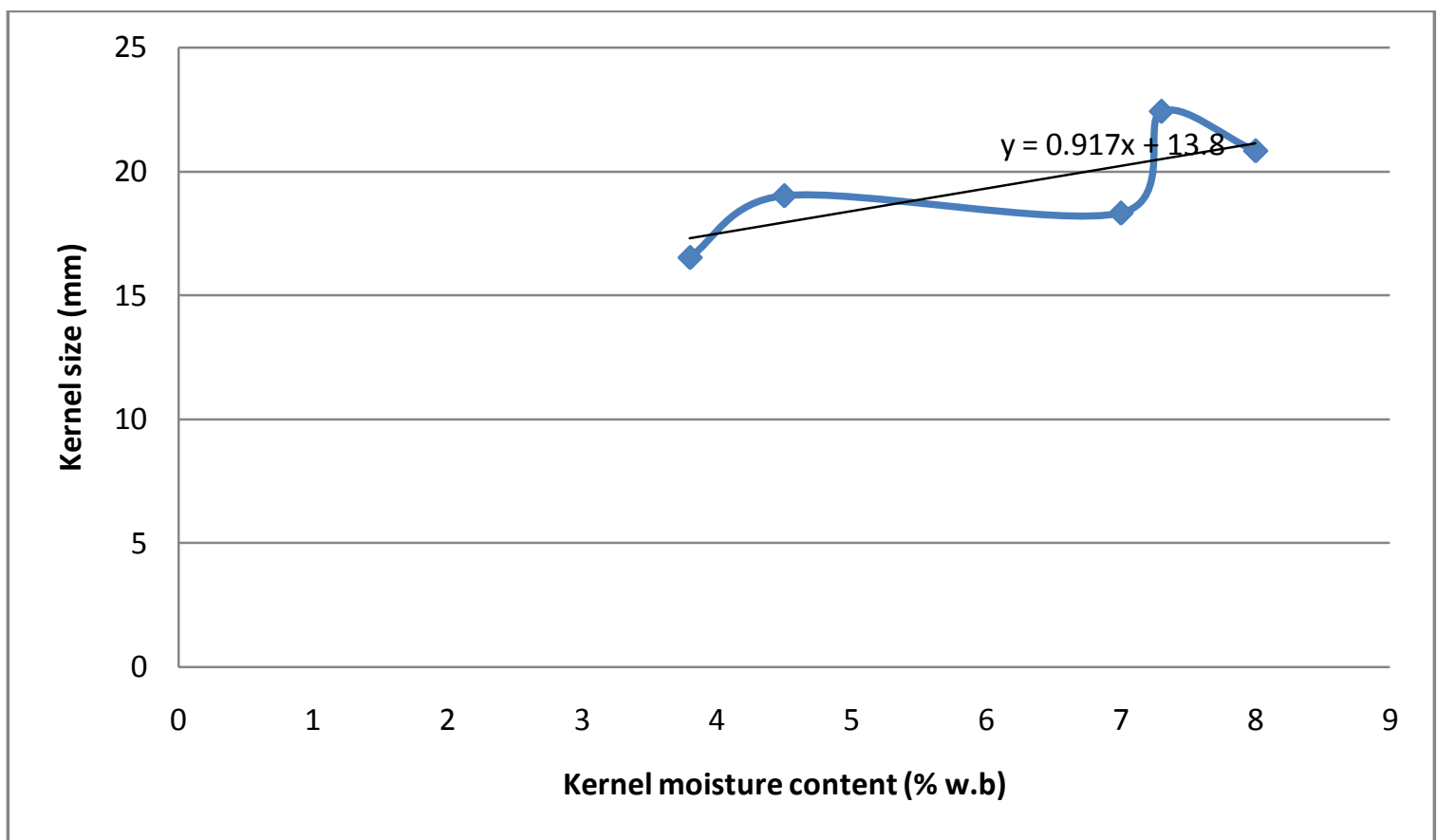

Figure 1 Graph showing trend of variation of kernel size with kernel moisture content

The trend indicates that kernel sizes increased as the kernel moisture content increased (positive coefficient of m.c.). This is plausible since drying causes kernel shrinkage and size reduction. The range of sphericity for the grades of palm kernels worked on was 0.67 (for small kernels) to 0.78 (for big kernels) with an average of 0.74 (Table 1). Thus the kernels would rather roll than slide on inclined surfaces. An examination of the sphericity values of the kernels vis-à-vis the moisture contents of the batches (Fig. 2) indicates that sphericity decreased as the moisture content of the kernels increased (negative coefficient of m.c.). This is attributable to non-uniform shrinkage due to non-uniform drying of kernels.

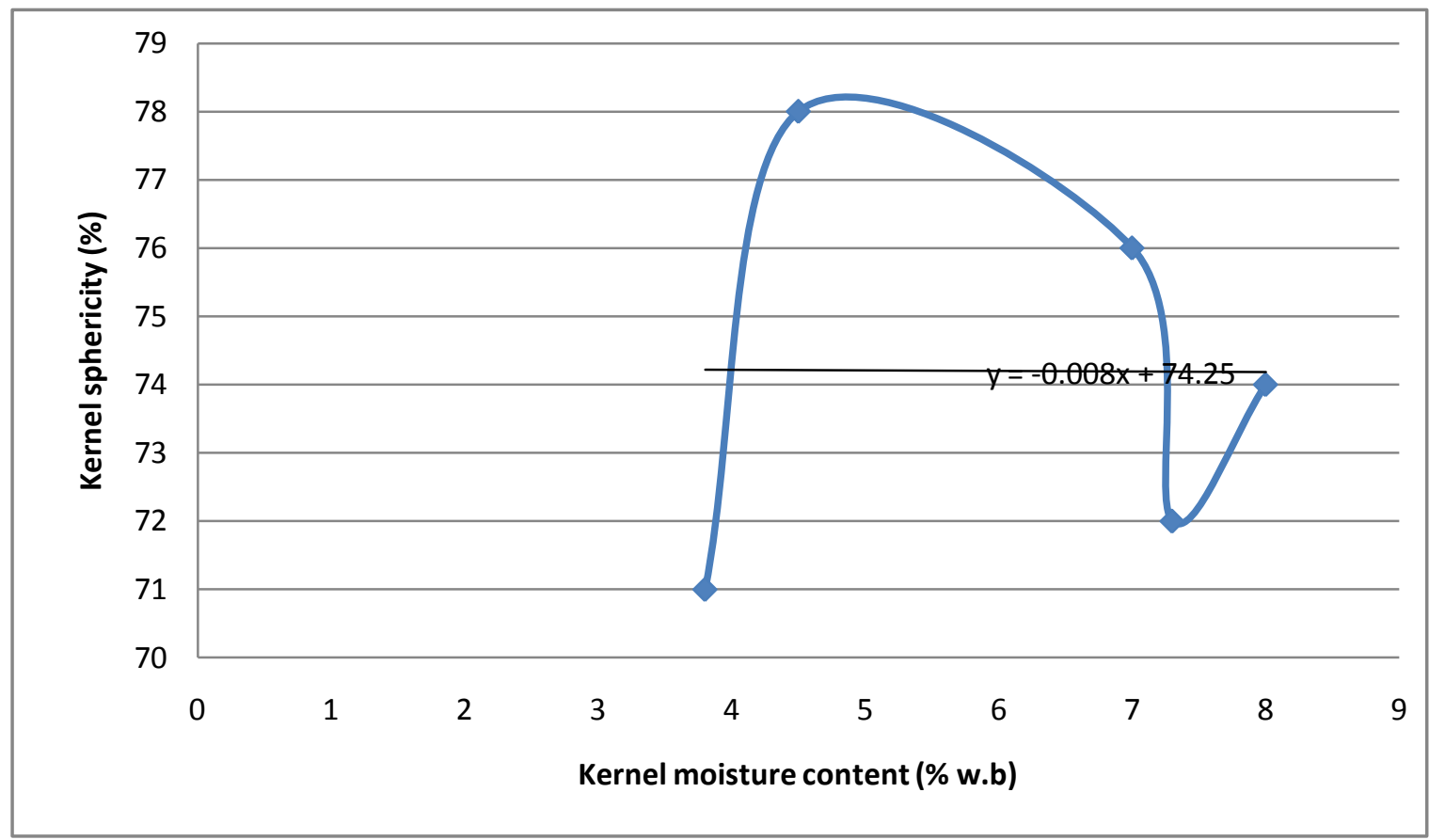

Figure 2 Graph showing trend of variation of kernel sphericity with kernel moisture content

The hardness values for the batches of palm kernels tested ranged between $10.21 \mathrm{kN} / \mathrm{m}^{2}$ and 10.50 $\mathrm{kN} / \mathrm{m}^{2}$ with an average value of $10.41 \mathrm{kN} / \mathrm{m}^{2}$ (Table 1). A plot of kernel hardness versus kernel moisture content (Fig. 3) shows that kernel hardness varied negatively with kernel moisture content. This is reasonable since drier kernels tend to be harder than moist ones. 


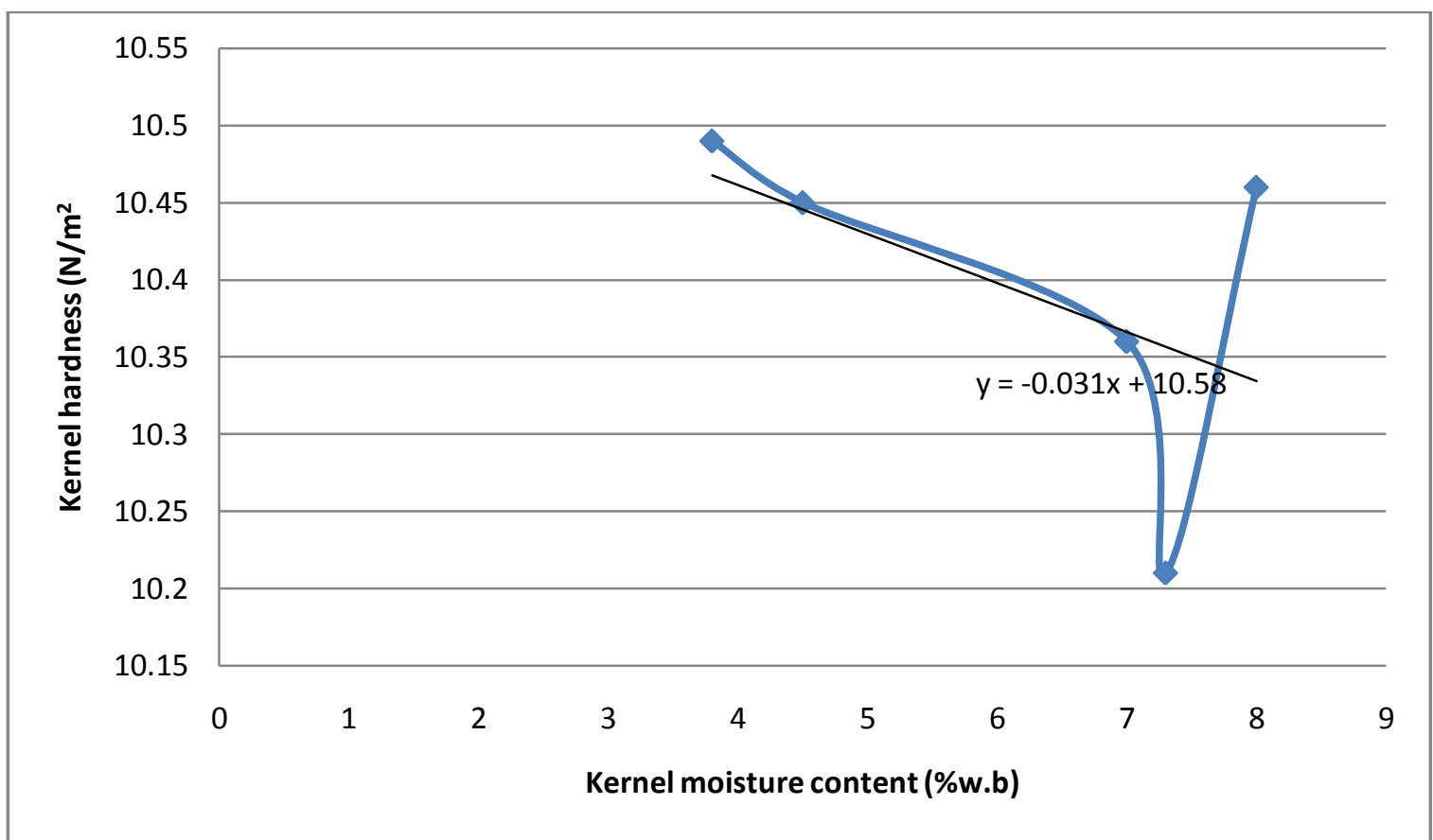

Fig. 3 Graph showing trend of variation of kernel hardness with kernel moisture content

The average bulk density of the various grades of kernels ranged between $550.14 \mathrm{~kg} / \mathrm{m}^{3}$ for grade $2^{\mathrm{A}}$ and $653.29 \mathrm{~kg} / \mathrm{m}^{3}$ for grade $5^{\mathrm{C}}$. Smaller sized kernels (grade $5^{\mathrm{C}}$ ) tended to have higher bulk density than bigger kernels (grade $1^{\mathrm{A}}$ and $2^{\mathrm{A}}$ ). The average value was $608.05 \pm 14.08 \mathrm{~kg} / \mathrm{m}^{3}$ (Table 1). A plot of bulk density versus moisture content for the different batches (Fig. 4) indicates that bulk density decreased with increasing kernel moisture content.

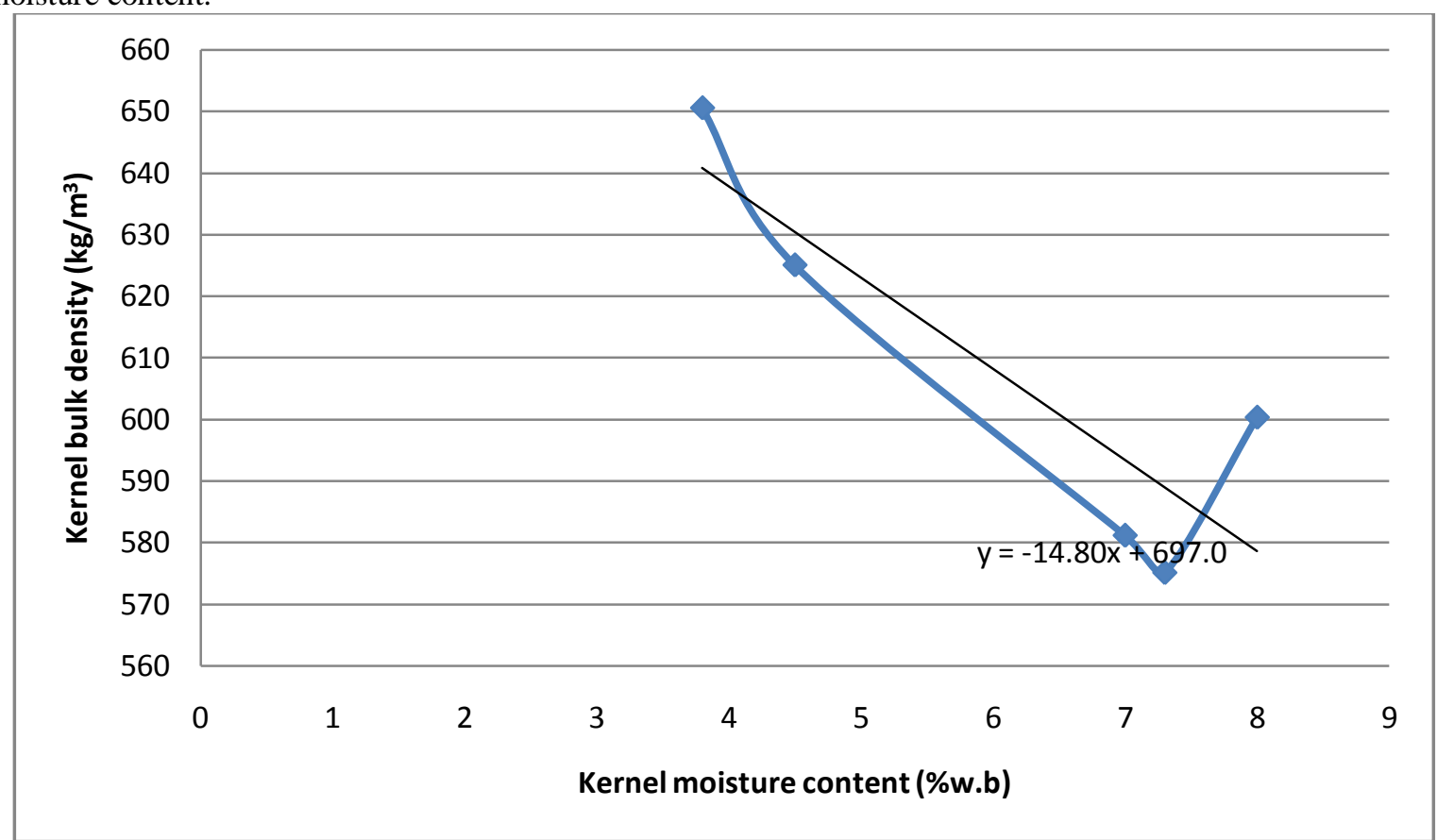

Fig. 4 Graph showing trend of variation of kernel bulk density with kernel moisture content

The solid density of the various grades of kernels ranged between $1.00 \mathrm{~g} / \mathrm{cm}^{3}$ and $1.32 \mathrm{~g} / \mathrm{cm}^{3}$. The average solid density, however, was $1.17 \mathrm{~g} / \mathrm{cm}^{3}$ for the unknown variety (Table 1). A plot of solid density versus moisture content of different kernel batches (Fig. 5) shows positive dependence of solid density on moisture content of kernels. 


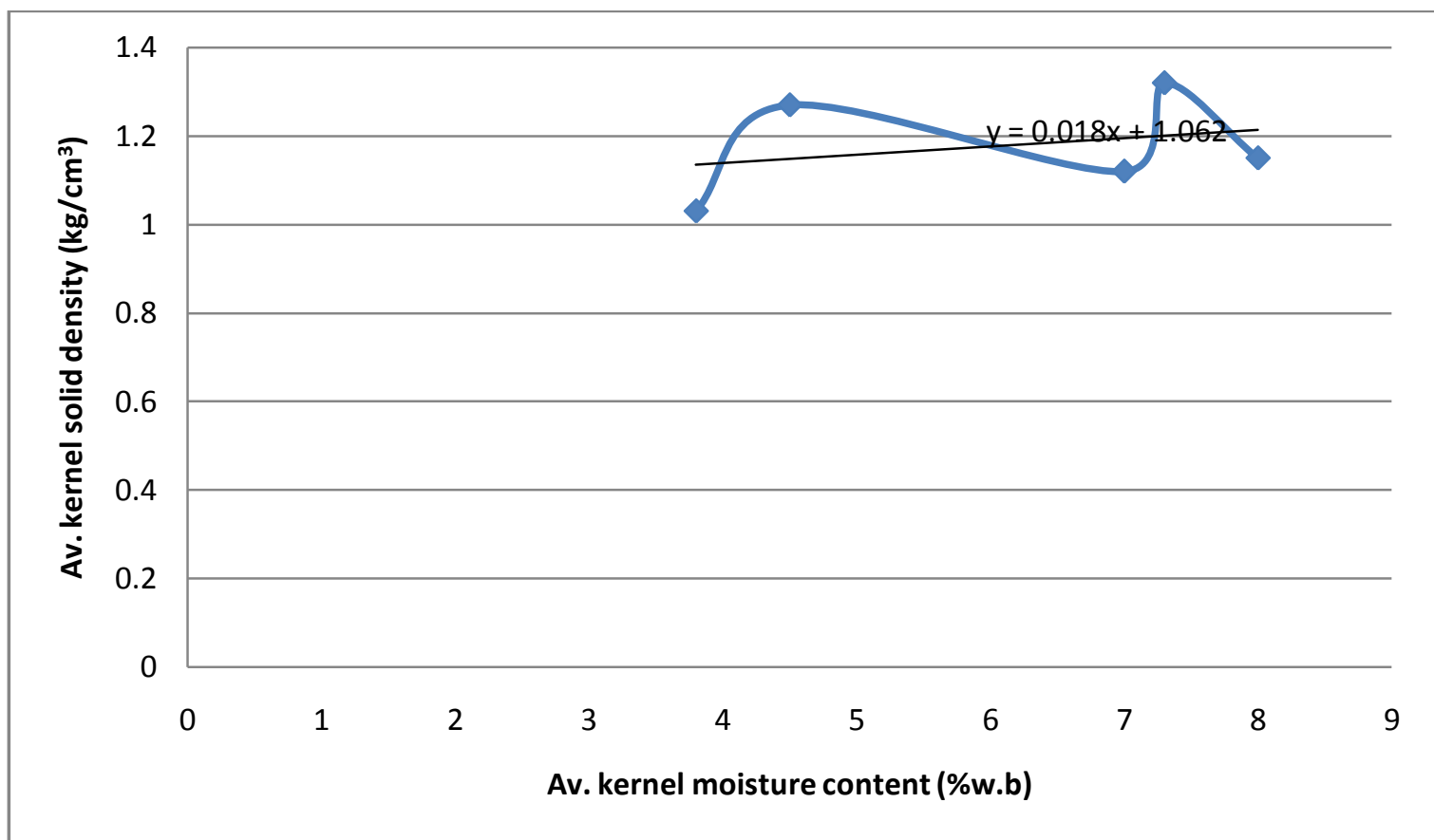

Figure 5 Graph showing trend of variation of kernel solid density with kernel moisture content

The porosity range was $38.2 \%$ for grade $2^{\mathrm{B}}$ to $56.4 \%$ for grade $1^{\mathrm{A}}$. The big-sized kernels tended to possess higher porosity values than the smaller sizes. The average porosity value for the eight grades worked on was $47.4 \pm 7.70 \%$ (Table 1). A plot of porosity versus moisture content of the different batches (Fig. 6) indicates that the porosity of palm kernels increased with kernel moisture content. This is because dry kernels pack more closely resulting in fewer voids.

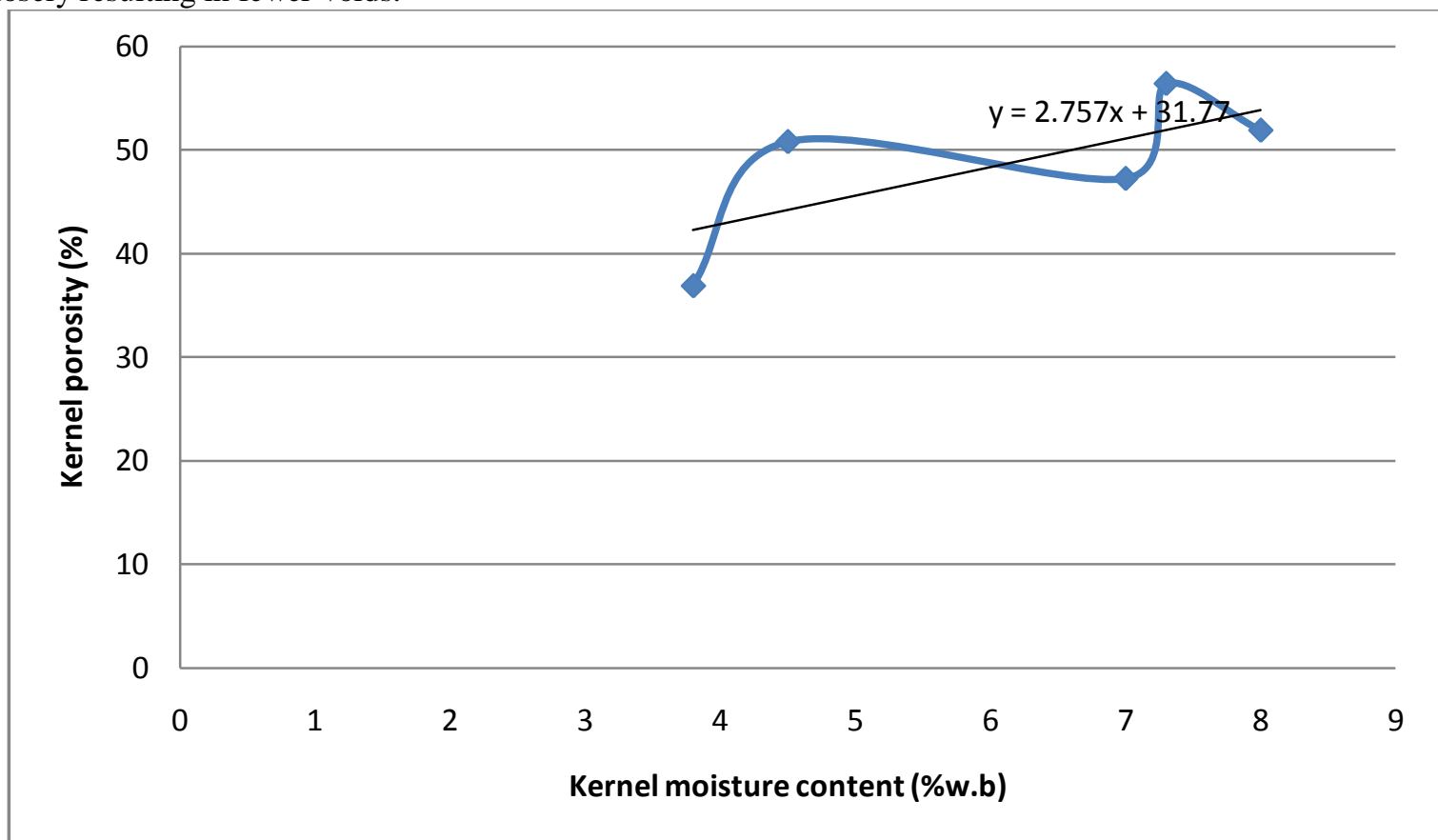

Figure 6 Graph showing trend of variation of kernel porosity with kernel moisture content

The average angles of repose were $44^{\circ}$ for grade $1^{\mathrm{A}}, 39^{\circ}$ for grade $4^{\mathrm{A}}, 35^{\circ}$ for grade $5^{\mathrm{B}}$, and $33^{\circ}$ for grade $5^{\mathrm{C}}$. Overall average angle of repose for the kernels was $37.75 \pm 1.33^{\circ}$ (Table 1).

The average coefficient of sliding friction of the kernels on plywood was $0.52 \pm 0.05$. It was $0.46 \pm 0.06$ on glass and $0.51 \pm 0.03$ on galvanized steel surfaces. The above values are equivalent to dynamic angles of repose of $27.47^{\circ}, 24.70^{\circ}$, and $27.0^{\circ}$ on plywood, glass, and galvanized steel surfaces respectively (Table 1). The results of the compression tests are presented in Table 2 . Grade $1^{\mathrm{A}}$ kernel exhibited the maximum average compressive 
yield load of $1037.5 \mathrm{~N}$ while the minimum average yield load of $805 \mathrm{~N}$ was exhibited by grade $4^{\mathrm{A}}$ kernels. The average yield load and deformation for the whole grades tested were found to be $1022 \mathrm{~N}$ and $4.4 \mathrm{~mm}$ respectively. A plot of compressive yield loads and moisture contents of the five different batches (Fig. 7) shows that the compressive yield loads varied negatively with moisture content. Thus drier kernels exhibited higher yield loads than their less dry samples.

Table 2: Compression test results for the palm kernels

\begin{tabular}{|c|c|c|c|c|}
\hline Grade & Av. kernel m.c. (\%w.b) & \multicolumn{3}{|c|}{ Loading axis Yield point load (N) Yield point deform. (mm) } \\
\hline $1^{\mathrm{A}}$ & 7.3 & Intermediate & 103750 & 5.50 \\
\hline $2^{\mathrm{A}}$ & 7.0 & " & 1058.33 & 4.88 \\
\hline $2^{\mathrm{B}}$ & 7.0 & $n$ & 1070.83 & 4.67 \\
\hline $3^{\mathrm{A}}$ & 4.5 & $n$ & - & - \\
\hline $4^{\mathrm{A}}$ & 8.0 & $n$ & 805.00 & 4.42 \\
\hline $4^{\mathrm{B}}$ & 8.0 & $n$ & 1075.00 & 3.58 \\
\hline $5^{B}$ & 3.8 & $n$ & 1029.17 & 3.25 \\
\hline $5^{c}$ & 3.8 & $n$ & 1081.25 & 4.63 \\
\hline Mean & 6.1 & $n$ & $1022.44=90.56$ & $4.42=0.67$ \\
\hline
\end{tabular}



Figure 7 Graph showing trend of variation of yield point load with kernel moisture content

\section{CONCLUSIONS}

The following conclusions could be drawn from this work:

1. The following average values of some engineering properties were determined for oil palm kernels of unknown variety sourced from some local markets in Nsukka, Enugu state, Nigeria: $19.09 \pm 2.01 \mathrm{~mm}, 13.84 \pm$ $1.17 \mathrm{~mm}$, and $10.82 \pm 1.43 \mathrm{~mm}$ for major, intermediate, and minor diameters respectively (resulting in a geometric mean diameter of $14.20 \pm 0.75 \mathrm{~mm}$ ); $608.05 \pm 14.08 \mathrm{~kg} / \mathrm{m}^{3}$ (for bulk density), $1.17 \pm 0.13 \mathrm{~g} / \mathrm{cm}^{3}$ (for solid density), $0.74 \pm 0.04$ (for sphericity), $10.41 \pm 0.09 \mathrm{kN} / \mathrm{m}^{2}$ (for hardness), $47.4 \pm 7.7 \%$ (for porosity), 37.75 $\pm 1.33^{\circ}$ (for angle of repose); compressive yield load of $1022.44 \pm 90.56 \mathrm{kN} / \mathrm{m}^{2}$; and average coefficient of sliding friction of 0.52 (on plywood), 0.51 (on galvanized steel), and 0.46 (on glass).

2. Analyses of the results indicated that palm kernel size, solid density, and porosity varied positively with kernel moisture content; whereas kernel bulk density, sphericity, hardness, and compressive strength varied negatively with kernel moisture content. This fact underscores the importance of stating the moisture content of experimental samples.

3. Again, the fact that any kernel whose major and intermediate diameters are greater than the aperture of a sieve would be retained on that sieve is important for the design and utilization of sieves for kernel grading and separation of kernels and contaminants. 
4. The major diameter range $(15.68 \mathrm{~mm}$ to $22.41 \mathrm{~mm}$ ) of the palm kernels used in this work indicated that the palm kernels were probably a mixtureofdura, tenera and pisifera varieties.

5. Given standard average sizes of dura, tenera, and pisifera varieties, any sample of oil palm kernels of unknown variety could be separated into its component varieties by appropriate sieving.

\section{REFERENCES}

[1] Mohsenin, N. N. 1986. Physical properties of plant and animal materials.Gordon and Breach Press, New York, USA.

[2] Alcali, I.D. and O. Guyen. 1996. Physical properties of peanut in Turkey. Agricultural mechanization in Asia, Africa and Latin America, 2(3), 55-59.

[3] Olaoye, J. O. 2000. Some physical properties of Castor nut relevant to the design of processing equipment. J. Agric. Eng. Res., 17(1), 11-118.

[4] Ogunsina, B. S., O. A. Koya and O. O. Adeosun. 2008. Deformation and Fracture of Dika nut under uniaxial compressive load. Int. Agrophyics, 22, 249-253.

[5] Akinoso, R., A. O. Raji J.C. Igbeka. 2009. Effects of compressive stress, feeding rate, and speed of rotation on Palm kernel oil yield. J. Food Eng., 93, 427-430.

[6] Makanjuola, G. A. 1972. A Study of Some of the Physical Properties of Melon Seeds. J. Agric. Eng. 17, 128-137.

[7] Dev, D. K., P. N. Satwadher and U. M. Ingle. 1982. Effects of variety and moisture content on selected physical properties of sorghum grain. Journal of Agricultural Engineering, Vol. xix, 2: 43-48.

[8] Gorial, B.Y and J. R. O’Callagham. 1990. Aerodynamic properties of grain/straw materials. J. Agric. Eng. Res., 46, 275-290.

[9] Gbadamosi, L. 2006. Some engineering properties of palm kernel seeds (PKS).J. Agric. Eng. Technol., 14, 58-66.

[10] Araullo, E.V., D. B. Padua and M. Graham. (Editors). 1976. Rice: Post-harvest Technology. International Development Research Centre, Canada, pp. 21-277.

[11] Hartley, C.W.S. 1977. The Oil Palm.Longman Publishers, London.

[12] Henderson, S. M. and R. L. Perry. 1980. Agricultural Process Engineering, $3^{\text {rd }}$ edition. The AVI Publishing Company Incorporated, Westport, Connecticut.

[13] Paulsen, M. R. 1978. Fracture resistance of soybean to compressive loading. Transactions of the American society of Agricultural Engineers. Vol. 21(6), 1210-1216.

[14] Ezeaku, G. A., C. O. Akubuo and A. P. Onwualu. 1998. Measurement of the resistance of Bambara Groundnut Seed to Compressive Loading. J. Agric. Eng. and Technol., 6, 12-18.

[15] Adebayo, A. A. 2004. Development and Performance Evaluation of a Motorized Palm Nut Cracker.In Proc. of the Nigerian Institution of Agricultural Engineers (NIAE), vol. 26: 326-330.

[16] Koya, O. A., A. Idowu and M. A. Faborode. 2004. Some properties of palm kernel and shell relevant in nut cracking and product separation. J. Agric. Eng. Technol., 12, 33-44.

[17] Ozumba, I. C. and S. I. Obiakor. 2007. Fracture resistance of palm kernel seed to compressive loading. In Proc. Nigerian Institution of Agricultural Engineers (NIAE), 29, 195-201.

[18] ASAE, 1993.Standard EPP-03 AND FE-03. St. Joseph, MI. 